\title{
From Cell-Free Protein Synthesis to Whole-Cell Biotransformation: Screening and Identification of Novel $\alpha$-Ketoglutarate-Dependent Dioxygenases for Preparative-Scale Synthesis of Hydroxy-L-Lysine
}

\author{
Jascha Rolf ${ }^{+} \mathbb{D}$, Philipp Nerke ${ }^{\dagger}$, Annette Britner, Sebastian Krick, Stephan Lütz $\mathbb{D}^{(D)}$ and Katrin Rosenthal *(D)

\begin{abstract}
Chair for Bioprocess Engineering, Department of Biochemical and Chemical Engineering, TU Dortmund University, D-44227 Dortmund, Germany; jascha.rolf@tu-dortmund.de (J.R.); philipp.nerke@tu-dortmund.de (P.N.); annette.britner@tu-dortmund.de (A.B.); sebastian.krick@tu-dortmund.de (S.K.); stephan.luetz@tu-dortmund.de (S.L.)

* Correspondence: katrin.rosenthal@tu-dortmund.de; Tel.: +49-231-755-5115

+ These authors have contributed equally to this work.
\end{abstract}

Citation: Rolf, J.; Nerke, P.; Britner, A.; Krick, S.; Lütz, S.; Rosenthal, K. From Cell-Free Protein Synthesis to Whole-Cell Biotransformation: Screening and Identification of Novel $\alpha$-Ketoglutarate-Dependent Dioxygenases for Preparative-Scale Synthesis of Hydroxy-L-Lysine.

Catalysts 2021, 11, 1038

https: / / doi.org/ 10.3390/ catal11091038

Academic Editors: Evangelos Topakas, David D. Boehr and Roland Wohlgemuth

Received: 30 June 2021

Accepted: 25 August 2021

Published: 27 August 2021

Publisher's Note: MDPI stays neutral with regard to jurisdictional claims in published maps and institutional affiliations.

Copyright: (c) 2021 by the authors. Licensee MDPI, Basel, Switzerland. This article is an open access article distributed under the terms and conditions of the Creative Commons Attribution (CC BY) license (https:/ / creativecommons.org/licenses/by/ $4.0 /)$.

\begin{abstract}
The selective hydroxylation of non-activated C-H bonds is still a challenging reaction in chemistry. Non-heme $\mathrm{Fe}^{2+} / \alpha$-ketoglutarate-dependent dioxygenases are remarkable biocatalysts for the activation of $\mathrm{C}-\mathrm{H}$-bonds, catalyzing mainly hydroxylations. The discovery of new $\mathrm{Fe}^{2+} / \alpha-$ ketoglutarate-dependent dioxygenases with suitable reactivity for biotechnological applications is therefore highly relevant to expand the limited range of enzymes described so far. In this study, we performed a protein BLAST to identify homologous enzymes to already described lysine dioxygenases (KDOs). Six novel and yet uncharacterized proteins were selected and synthesized by cell-free protein synthesis (CFPS). The subsequent in vitro screening of the selected homologs revealed activity towards the hydroxylation of L-lysine (Lys) into hydroxy-L-lysine (Hyl), which is a versatile chiral building block. With respect to biotechnological application, Escherichia coli whole-cell biocatalysts were developed and characterized in small-scale biotransformations. As the whole-cell biocatalyst expressing the gene coding for the KDO from Photorhabdus luminescens showed the highest specific activity of $8.6 \pm 0.6 \mathrm{U} \mathrm{gCDW}^{-1}$, it was selected for the preparative synthesis of Hyl. Multi-gram scale product concentrations were achieved providing a good starting point for further bioprocess development for Hyl production. A systematic approach was established to screen and identify novel $\mathrm{Fe}^{2+} / \alpha$-ketoglutarate-dependent dioxygenases, covering the entire pathway from gene to product, which contributes to accelerating the development of bioprocesses for the production of value-added chemicals.
\end{abstract}

Keywords: $\mathrm{KDO} ; \mathrm{Fe}^{2+} / \alpha$-ketoglutarate-dependent dioxygenase; chaperones; cell-free protein synthesis (CFPS); L-lysine; hydroxy-L-lysine

\section{Introduction}

Non-heme $\mathrm{Fe}^{2+} / \alpha$-ketoglutarate-dependent dioxygenases constitute a large superfamily of enzymes. They are capable of catalyzing a plethora of different reactions, such as desaturations, epoxidations, halogenations, oxidations, cyclizations, and predominantly hydroxylations $[1,2]$. In recent years, $\mathrm{Fe}^{2+} / \alpha$-ketoglutarate-dependent dioxygenases have been discovered, which hydroxylate L-lysine (Lys) to produce hydroxy-L-lysine (Hyl) [3,4]. The enzymes have been termed KDO for lysine dioxygenase [3]. Depending on the respective KDO, different isomers are formed with high regio- and stereospecificity. Hyl is a molecule of industrial interest as it is a building block for the synthesis of a variety of pharmacologically relevant molecules, such as the HIV protease inhibitor palinavir [5,6], or newly identified drug candidates such as tambromycin (anticancerogenic activity), cepafungin I or glidobactin A, both of which are proteasome inhibitors [7-9]. It can also be 
used for the generation of chiral amino alcohols, which represent relevant chiral building blocks $[10,11]$. Therefore, the discovery of novel enzymes able to catalyze challenging reactions such as the selective hydroxylation of non-activated C-H bonds in Lys is of high importance.

To screen and identify novel enzymes, in vitro or cell-free protein synthesis (CFPS) has become an established tool for rapid transcription and translation [12-14]. CFPS can complement traditional in vivo protein synthesis to accelerate the discovery of novel enzymes or enzyme variants [15]. However, a common challenge is that proteins, when synthesized with heterologous systems, often do not fold properly and therefore become insoluble. Molecular chaperones prevent protein aggregation and promote protein folding. Exogenous addition of molecular chaperone proteins has effectively facilitated the synthesis of various soluble proteins in CFPS systems [16]. Alternatively, the chaperones can be directly synthesized in the source organisms before CFPS extract preparation [17]. To accomplish this, Escherichia coli strains are transformed with plasmids encoding different sets of molecular chaperones. These are synthesized during growth of the strain, which serves as the basis for the cell extract. The extract thus contains not only all components for transcription and translation, but also chaperones that will support the synthesis of soluble protein. This avoids the time-consuming and laborious synthesis and purification of chaperones, or the expensive use of commercially available chaperones. Alternatively, the CFPS reaction mix can be used first to synthesize the chaperones, and only in a second step does the synthesis of the target protein take place [18]. In this case, it is mandatory that the synthesis solution is refreshed after the first synthesis step, as the systems will otherwise have a lower synthesis performance.

In this study, chaperone-enriched CFPS extracts were developed to synthesize KDOs, which are difficult to express in soluble form in E. coli $[3,8]$. Five different chaperones containing CFPS systems were prepared from E. coli strains and tested to screen novel and putative KDOs (Figure 1). The CFPS systems allowed the efficient synthesis of soluble enzymes without the need for exogenous addition or co-expression of folding effectors. Subsequent activity assays demonstrated the successful hydroxylation of Lys to Hyl for several KDOs, including six novel and previously biochemically uncharacterized and undescribed enzymes. The novel KDOs were further characterized in whole-cell systems using recombinant $E$. coli. One newly identified homolog was selected and applied in a resting-cell biotransformation on a preparative scale.

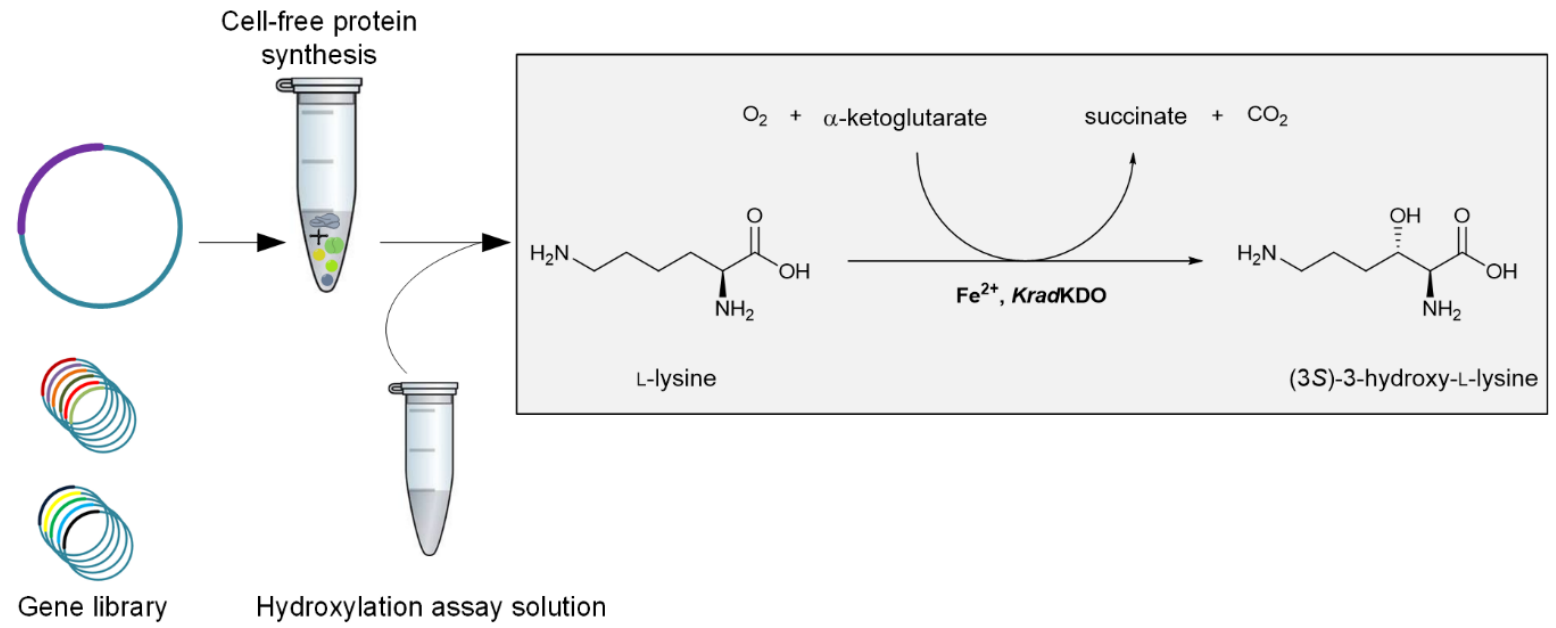

Figure 1. Schematic procedure for screening novel lysine dioxygenases (KDOs) with cell-free protein synthesis (CFPS). Exemplary reaction for the KDO from Kineococcus radiotolerans (KradKDO). 


\section{Results}

\subsection{Sequence Similarity Search for Novel KDOs in Bacteria}

In this study, 13 enzymes from different bacteria (Figure 2) were tested for hydroxylation of Lys to Hyl, of which six were uncharacterized enzymes. To identify novel KDOs belonging to the superfamily of $\mathrm{Fe}^{2+} / \alpha$-ketoglutarate-dependent dioxygenases, we searched for enzyme homologs to the known KDOs, which were discovered by Baud et al. 2014 [3] and Hara et al. 2017 [4], using Protein Basic Local Alignment Search Tool (BLAST) (NCBI, Bethesda, MD, USA). These enzymes catalyze the regio- and stereospecific hydroxylation of Lys to form either (3S)-3-hydroxy-L-lysine or (4R)-4-hydroxy-L-lysine and were grouped in the clavaminate synthase-like family (IPR014503) [19]. Our BLAST search led to protein sequences of the putative KDOs KrhiKDO from Kineococcus rhizospharae and MintKDO from Mycobacterium interjectum (Figure 3A). They share a protein sequence identity of $47.32 \%$ and $42.11 \%$, compared to the sequence of CaciKDO from Catenulispora acidiphila, respectively.

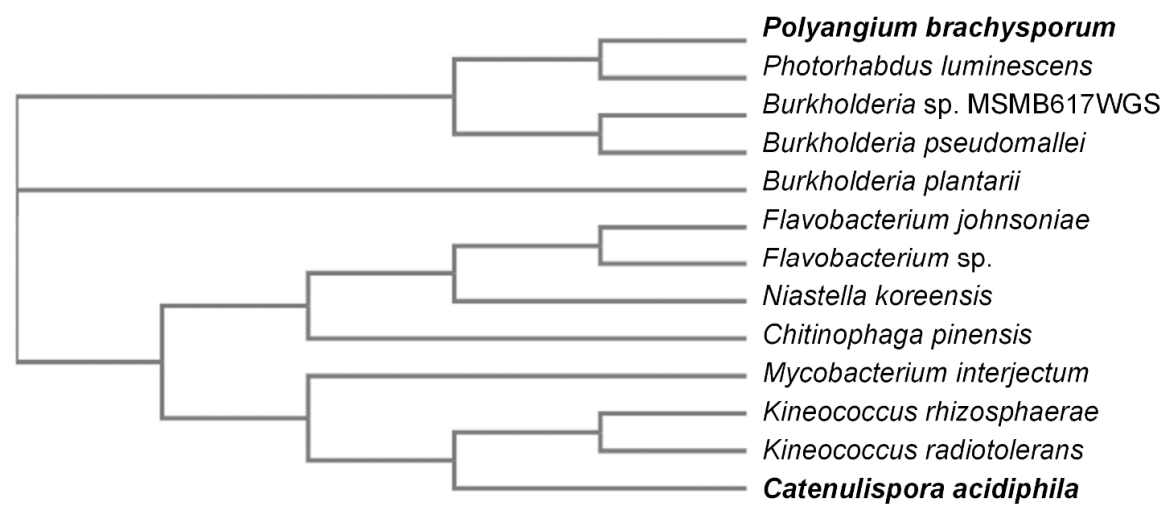

Figure 2. Phylogenetic tree of the organisms of origin of the known and putative KDOs considered in this study. The figure was created using the EMBL-EBI Web Service [20] with the respective protein sequences. 
A

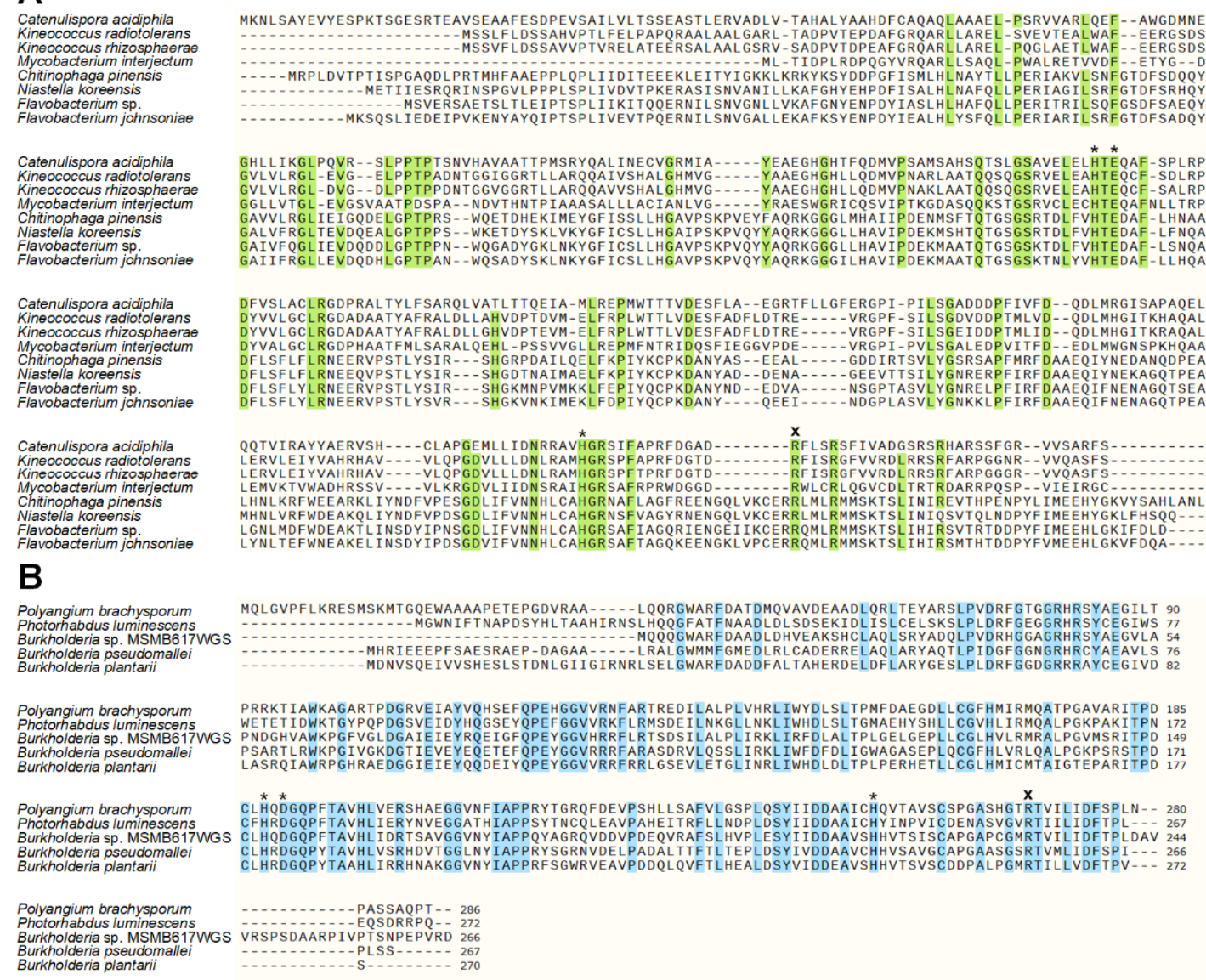

Figure 3. (A) Multiple sequence alignment of the KDO from Catenulispora acidiphila (CaciKDO) with homologs from different species. (B) Multiple sequence alignment of the KDO from Polyangium brachysporum (BpraKDO) with homologs from different species. Shading indicates a consensus sequence above a threshold of $80 \%$. The alignment was generated using MUSCLE (SnapGene ${ }^{\circledR \circledast}$, GSL Biotech LLC, Chicago, IL, USA, Version 4.3.11). The asterisk depicts the three amino acids, which form the metal binding triad. The $\mathrm{x}$ denotes the arginine, which is involved in $\alpha$-ketoglutarate $(\alpha-\mathrm{KG})$ binding. Positions were adopted from crystal structures and homology models [9,19].

In 2019, Amatuni et al. discovered that the enzyme GlbB, from the glidobactin synthesis cluster of Polyangium brachysporum (now reclassified as Schlegelella brevitalea sp. nov. [21]) also belongs to the $\mathrm{Fe}^{2+} / \alpha$-ketoglutarate-dependent dioxygenase family and acts as KDO to produce (4S)-4-hydroxy-L-lysine [9]. This enzyme is therefore termed PbraKDO in our study. Interestingly, as the authors mentioned, this enzyme only shares a very low sequence identity with the KDOs discovered previously (e.g., $11.7 \%$ to CaciKDO). PbraKDO was found to form a novel cluster in the PF10014 (IPR018724) family [9]. The phylogenetic assignment clearly shows the distinction between the two different groups of KDOs belonging to the superfamily of $\mathrm{Fe}^{2+} / \alpha$-ketoglutarate-dependent dioxygenases (Figure 2).

Using the protein sequence of PbraKDO as a query sequence, we found almost 100 protein sequences ranging from a maximum of $59 \%$ identity to $31 \%$ identity. We selected four sequences with different phylogenetic distance to PbraKDO for our study (Figure 2, Figure 3B); the putative KDOs PlumKDO from Photorhabdus luminescens (56.73\% identity), BspeKDO from Burkholderia species MSMB617WGS (57.48\% identity), BpseKDO from Burkholderia pseudomallei (51.89\% identity) and BplaKDO from Burkholderia plantarii (50.41\% identity). These protein sequences were all annotated as belonging to the $\mathrm{Fe}^{2+} / \alpha-$ ketoglutarate-dependent dioxygenase family.

The enzymes from the group of $C$. acidiphila are all larger in size than the KDO from P. brachysporum and its homologs (Figure 3). The alignments show the conserved sites 
for metal ion binding as well as the conserved arginine, which is involved in the binding of $\alpha$-ketoglutarate $(\alpha-\mathrm{KG})$. $\mathrm{Fe}^{2+}$ binding is usually facilitated by a 2 -His-1-carboxylate facial triad [22]. While $\mathrm{Fe}^{2+}$ binding of the first group is facilitated by His-Glu-His motif (Figure 3A), it is constituted by a His-Asp-His motif in the second group (Figure 3B).

\subsection{Cell-Free Protein Synthesis Identifies Novel KDOs}

CFPS can be performed within a few hours and thus accelerates the screening of enzyme variants $[13,15]$. Therefore, we performed the synthesis of known KDOs and yet undescribed homologs in an E. coli-based CFPS system with plasmids carrying DNA templates.

The protein syntheses were investigated with SDS-PAGE analysis (Figure 4A, Supplementary Materials Figures S3-S26). Corresponding protein bands could be proven for most protein homologs. For the new variants, no synthesis could be confirmed only for the homolog derived from B. plantarii. However, the successful synthesis cannot be ruled out due to the complex protein composition of the CFPS mix in combination with insufficient protein concentrations. In some cases, prominent bands of $E$. coli's endogenous proteins overlaid the area for the associated sizes. Therefore, no preselection of expressible or non-expressible homologs was carried out and all CFPS reactions were screened for activity in subsequent hydroxylation assays combined with LC-MS-based analysis. The previously described KDOs showed activity towards the hydroxylation of Lys, proven by the formation of Hyl (Figure 4B). Previous studies already identified the products of CpinKDO, NkorKDO, FspeKDO, FjohKDO to be (4R)-4-hydroxy-L-lysine and CaciKDO and KradKDO to be (3S)-3-hydroxy-L-lysine [3,4,19]. The product of PbraKDO was identified to be (4S)-4-hydroxy-L-lysine [8,9]. We were able to distinguish between 5-hydroxy-DL-lysine (analytical standard) and (4R)-4-hydroxy-L-lysine with our HPLC-methods. Unfortunately, (3S)-3-hydroxy-L-lysine and (4S)-4-hydroxy-L-lysine eluted at the same retention time, so no clear discrimination was possible. However, based on the phylogenetic origin, it is likely that KrhiKDO and MintKDO form (3S)-3-hydroxy-L-lysine and that PlumKDO, BspeKDO, BpseKDO and BplaKDO produce (4S)-4-hydroxy-L-lysine. The products still need to be investigated further to determine their absolute configuration. For that, synthesis in preparative scale of all products would be required for chemical derivatization and NMR analysis, which was beyond the scope of this work. Nevertheless, these results confirm the applicability of CFPS in combination with a hydroxylation assay for KDOs.

Remarkably, four of six novel KDOs, which have never been characterized biochemically before, catalyzed the synthesis of more than $50 \mu \mathrm{M} \mathrm{Hyl}$ and were thus confirmed as KDOs. Only the enzyme homologs originating from $M$. interjectum and B. species MSMB617WGS produced just trace amounts of Hyl. In negative controls with the CFPS mix but without a DNA template, Hyl could not be detected after $20 \mathrm{~h}$. The highest product concentration of $3.66 \pm 0.16 \mathrm{mM}$ ( $\sim 37 \%$ yield) was achieved by the KDO of Flavobacterium species. As the CFPS reaction solution is a complex mixture, it is possible that enzymes from E. coli metabolism, which are present in the extract, degraded Lys or $\alpha-K G$. Moreover, oxygen limitation, oxidation of $\mathrm{Fe}^{2+}$, or chelation by components of the CFPS reaction solution might be reasons for the incomplete conversion in the hydroxylation assay. It should be noted that identical reaction conditions were tested for all enzymes. However, it has already been described that some KDOs showed higher activities under different conditions, such as increased or decreased temperatures and $\mathrm{pH}$ [4]. Nevertheless, higher product concentration may indicate better protein expression, higher enzyme stability or activity, and thus indicate a suitable biocatalyst for the biotransformation of Lys into Hyl. 


\section{A}

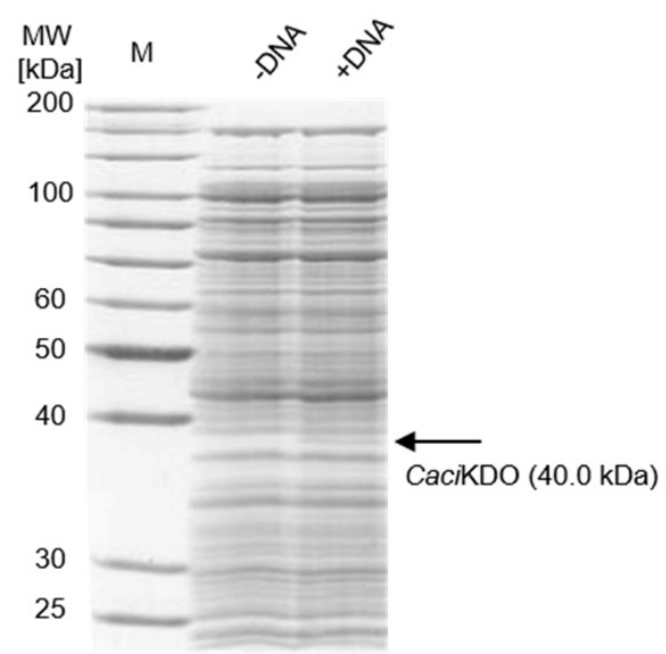

B

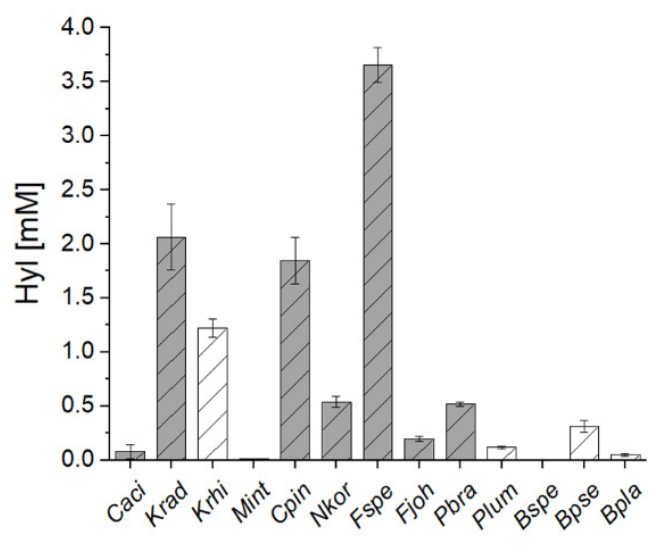

Figure 4. (A) SDS-PAGE gel image of cell-free synthesized CaciKDO. M, marker; -DNA, CFPS mix without plasmid template; +DNA, CFPS mix containing the plasmid template for CaciKDO. (B) Hydroxy-L-lysine (Hyl) concentrations achieved in in vitro hydroxylation assays for cell-free synthesized KDOs (Caci, Catenulispora acidiphila; Krad, Kineococcus radiotolerans, Krhi, Kineococcus rhizosphaerae; Mint, Mycobacterium interjectum; Cpin, Chitinophaga pinensis; Nkor, Niastella koreensis; Fspe, Flavobacterium sp.; Fjoh, Flavobacterium johnsoniae; Pbra, Polyangium brachysporum; Plum, Photorhabdus luminescens; Bspe, Burkholderia sp. MSMB617WGS; Bpse, Burkholderia pseudomallei; Bpla, Burkholderia plantarii). Assays were performed on a $100 \mu \mathrm{L}$ scale with $10 \mathrm{mM}$ L-lysine (Lys) and 20\% v/v protein solution for $20 \mathrm{~h}$. Protein homologs are sorted by phylogenetic distance. Grey bars indicate described KDOs, while white bars indicate undescribed KDOs. Error bars are a result of biological duplicates.

Hence, the combination of CFPS and the in vitro hydroxylation assay is very well suited for the screening and identification of KDOs. A further simplification and increase in speed would be the use of PCR-based linear DNA templates, thus eliminating any cloning steps [23]. This would allow a much larger number of proteins to be screened for biocatalytic activity in a very short time.

\subsection{Chaperone-Assisted Expression Can Improve the Productivity of Cell-Free Synthesized KDOs}

In a previous study, suboptimal protein yields of CaciKDO and PbraKDO were obtained due to the synthesis of insoluble proteins $[7,8]$. This issue could be mostly solved by the co-expression of chaperones, in this case, GroEL and GroES. In our study, similar problems were noticed when we analyzed the soluble and total fraction of the cell-free synthesized KDOs (Figure 5). Since correct three-dimensional folding is critical for full enzyme function, these insoluble proteins are usually inactive.

Therefore, we decided to test chaperone-enriched cell extracts for the CFPS of KDOs, which could lead to a higher fraction of soluble enzyme and thereby increased hydroxylation activity. We generated five additional cell extracts, in which the commercially available plasmids pG-KJE8, pKJE7, pGro7, pG-Tf2, and pTf16 were used for the expression of different chaperone sets, consisting of DnaK, DnaJ, GrpE, GroES, GroEL, and tig. These extracts were used for the synthesis of the 13 enzyme variants, which were tested in subsequent hydroxylation assays (Table 1). 


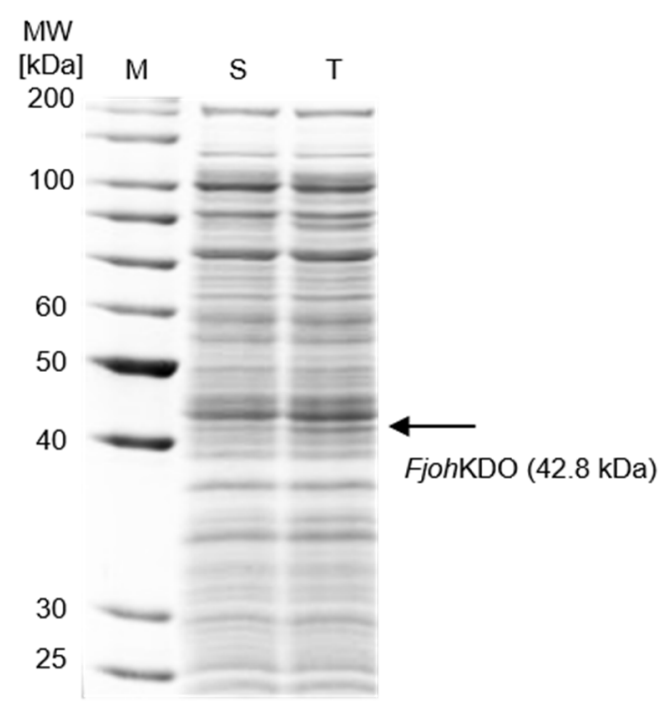

Figure 5. Exemplary SDS-PAGE gel image of cell-free synthesized KDO from Flavobacterium johnsoniae (FjohKDO). M, marker; T, total protein; S, soluble protein fraction (obtained through centrifugation for $10 \mathrm{~min}$ at $18,000 \times g)$.

Table 1. Hyl concentrations in $\mathrm{mM}$ achieved in in vitro hydroxylation assays for cell-free synthesized KDOs with chaperone-enriched cell extracts. Assays were performed on a $100 \mu \mathrm{L}$ scale with $10 \mathrm{mM}$ Lys and $20 \% \mathrm{v} / \mathrm{v}$ protein solution for $20 \mathrm{~h}$. Coloring applies to each row individually; dark green is the highest value and red is the lowest value. Values below $0.02 \mathrm{mM}$ are dark red. Standard deviations are a result of biological duplicates.

\begin{tabular}{ccccccc}
\hline Reference & $\begin{array}{c}\text { DnaK, DnaJ, } \\
\text { GrpE, GroES, } \\
\text { GroEL }\end{array}$ & $\begin{array}{c}\text { DnaK, } \\
\text { DnaJ, } \\
\text { GrpE }\end{array}$ & $\begin{array}{c}\text { GroES, } \\
\text { GroEL }\end{array}$ & $\begin{array}{c}\text { GroES, } \\
\text { GroEL, tig }\end{array}$ & tig \\
\hline Caci & $0.08 \pm 0.06$ & $0.06 \pm 0.00$ & $0.03 \pm 0.01$ & $0.05 \pm 0.00$ & $0.07 \pm 0.01$ & $0.02 \pm 0.00$ \\
Krad & $2.07 \pm 0.30$ & $0.83 \pm 0.54$ & $0.99 \pm 0.34$ & $0.17 \pm 0.05$ & $2.02 \pm 0.03$ & $1.65 \pm 0.09$ \\
Krhi & $1.22 \pm 0.08$ & $0.15 \pm 0.02$ & $0.32 \pm 0.01$ & $0.06 \pm 0.01$ & $0.46 \pm 0.01$ & $0.02 \pm 0.00$ \\
Mint & $0.01 \pm 0.00$ & $0.02 \pm 0.00$ & $0.02 \pm 0.00$ & $0.01 \pm 0.00$ & $0.02 \pm 0.00$ & $0.01 \pm 0.00$ \\
Cpin & $1.85 \pm 0.21$ & $0.48 \pm 0.24$ & $1.55 \pm 0.41$ & $0.34 \pm 0.01$ & $0.30 \pm 0.02$ & $0.05 \pm 0.00$ \\
Nkor & $0.54 \pm 0.05$ & $0.28 \pm 0.08$ & $0.44 \pm 0.04$ & $0.02 \pm 0.00$ & $0.03 \pm 0.00$ & $0.01 \pm 0.00$ \\
Fspe & $3.66 \pm 0.16$ & $3.13 \pm 0.98$ & $2.68 \pm 0.20$ & $0.23 \pm 0.01$ & $0.27 \pm 0.02$ & $0.09 \pm 0.00$ \\
Fjoh & $0.20 \pm 0.02$ & $0.08 \pm 0.01$ & $0.15 \pm 0.01$ & $0.01 \pm 0.00$ & $0.02 \pm 0.00$ & $0.01 \pm 0.00$ \\
Pbra & $0.52 \pm 0.02$ & $0.95 \pm 0.20$ & $0.31 \pm 0.07$ & $0.03 \pm 0.02$ & $0.08 \pm 0.04$ & $0.03 \pm 0.00$ \\
Plum & $0.12 \pm 0.01$ & $0.12 \pm 0.01$ & $0.08 \pm 0.02$ & $0.01 \pm 0.00$ & $0.01 \pm 0.00$ & $0.00 \pm 0.00$ \\
Bspe & $0.00 \pm 0.00$ & $0.01 \pm 0.00$ & $0.01 \pm 0.00$ & $0.01 \pm 0.00$ & $0.01 \pm 0.00$ & $0.01 \pm 0.00$ \\
Bpse & $0.31 \pm 0.06$ & $0.72 \pm 0.12$ & $0.33 \pm 0.01$ & $0.05 \pm 0.01$ & $0.15 \pm 0.09$ & $0.03 \pm 0.02$ \\
Bpla & $0.05 \pm 0.01$ & $0.11 \pm 0.01$ & $0.02 \pm 0.00$ & $0.01 \pm 0.00$ & $0.01 \pm 0.00$ & $0.01 \pm 0.00$ \\
\hline
\end{tabular}

The concentrations obtained after $20 \mathrm{~h}$ incubation with $10 \mathrm{mM}$ Lys varied from 0 to a maximum of $3.66 \pm 0.16 \mathrm{mM}$, which was still obtained with FspeKDO in the cell extract without chaperones. Thus, the maximum obtained yield was $37 \%$, which is significantly lower than the expected yield of up to $100 \%$ [4,7,8]. Lys or Hyl degrading enzymes in the complex cell extract or insufficient KDO activity or stability may cause the incomplete conversion of Lys into Hyl. The CFPS reaction volume is too low and complex for a more detailed analysis of the product and substrate progress, so no definite statement can be made at this point. In most cases, lower Hyl concentrations were achieved in the chaperone-containing synthesis mixes compared to the reference. This could be explained by interactions between the enzymes and the chaperones. The chaperones might have a negative influence on the activity or overall stability of the biocatalysts. A previous study showed that an excess of DnaK, DnaJ, and GrpE was inhibitory for protein production, and it was suggested that increased proteolysis could be the explanation [24]. Interestingly, enhanced synthesis in the presence of chaperones cannot be attributed to individual 
chaperones, but rather occurs in the complex mixture of all chaperones. In the case of the PbraKDO homologs, the combination of DnaK, DnaJ, GrpE, GroES, and GroEL increased the product concentrations for all active variants. Increases of more than $100 \%$ were achieved for BpseKDO and BplaKDO. The enzyme variants MintKDO and BspeKDO, which showed only marginal Hyl production in the initial screening, did not show any higher product concentrations in these experiments either. Furthermore, a tendency can be seen that the respective chaperone sets show a similar effect for phylogenetically closely related variants. Thus, chaperone-assisted CFPS is a good tool for the rapid screening of suitable chaperones for the synthesis of difficult-to-synthesize proteins and can lead to more efficient biocatalysts.

\subsection{Heterologous Expression of Novel KDOs}

PbraKDO is known to catalyze the hydroxylation of Lys to (4S)-4-hydroxy-L-lysine. The enzyme and its respective homologs have not yet been characterized for biotechnological application in a whole-cell biocatalyst format. Since all homologs of PbraKDO were shown to synthesize Hyl in the CFPS experiments, we next investigated them as whole-cell biocatalysts with E. coli. Although BspeKDO yielded only trace amounts of $\mathrm{Hyl}$ in the screening experiments, we decided to include it in the whole-cell experiments to test the transferability of our approach. All proteins were successfully synthesized in vivo in E. coli BL21 (DE3), but the percentage of the soluble protein fraction varied significantly among the different homologs (Figure 6A). Especially for BspeKDO, the heterologous expression led almost exclusively to insoluble protein. We then tested the different strains in smallscale resting-cell biotransformations for hydroxylation of Lys and determined the activity of the biocatalysts (Figure 6B). No activity was detected for E. coli BL21 (DE3) pET-24a(+)$B s p e K D O$. This might be a result of misfolded protein and is in accordance with the results obtained from CFPS experiments. E. coli BL21 (DE3) pET-24a(+)-BplaKDO and PlumKDO exhibited the highest activity of the tested whole-cell biocatalysts of about $2 \mathrm{U} \mathrm{g}_{\mathrm{CDW}}{ }^{-1}$. At first glance, these results seem to contradict the results from the in vitro hydroxylation assays, where PbraKDO and BpseKDO gave the highest product concentrations of the five considered enzymes. However, it should be noted that the in vivo and in vitro expression conditions are very different, and the biotransformation conditions also differ from each other. Despite that, the combination of CFPS and the in vitro hydroxylation assay correctly identified the four most active and therefore most promising enzyme homologs.

To test whether the whole-cell biotransformation is limited by mass transfer, we performed resting-cell biotransformations with the addition of $1 \% v / v$ Triton X-100 as permeabilization agent (Figure 6B). As before, $\alpha-\mathrm{KG}$ was added in twofold excess relative to Lys to avoid limitation by insufficient co-substrate concentrations. The permeabilization led to a vast increase in activity for the four active biocatalysts. E. coli BL21 (DE3) pET$24 \mathrm{a}(+)$-PlumKDO exhibited the highest activity with $8.6 \pm 0.6 \mathrm{U} \mathrm{gCDW}^{-1}$, which is more than a threefold improvement compared to the assay without Triton X-100. The activity is on a similar scale as other E. coli-based whole-cell biocatalysts from the study of Hara et al. (5-27 $\mathrm{U} \mathrm{g}_{\mathrm{CDW}}{ }^{-1}$, calculated from the given specific productivities [4]). 


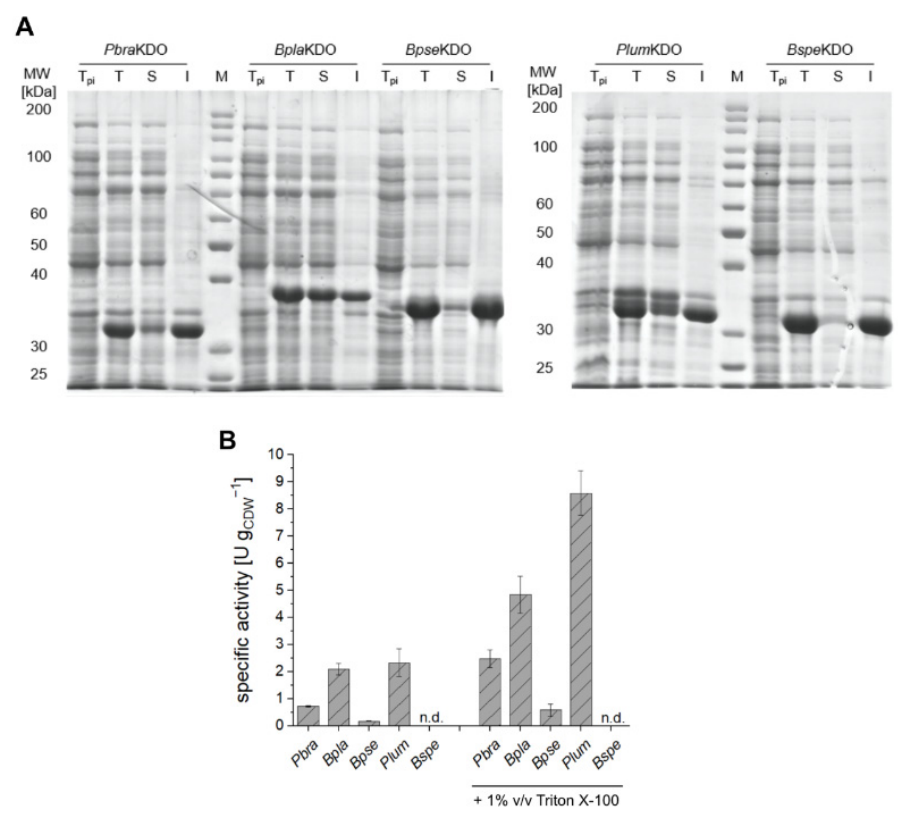

Figure 6. (A) SDS-PAGE gel image of the protein content of E. coli BL21 (DE3) whole-cell biocatalysts. $\mathrm{M}$, marker; $\mathrm{T}_{\mathrm{pi}}$, total protein pre-induction; $\mathrm{T}$, total protein; $\mathrm{S}$, soluble protein fraction; $\mathrm{I}$, insoluble protein fraction. Molecular weights of the proteins of interest are PbraKDO $32.5 \mathrm{kDa}$, BplaKDO 31.5 kDa, BpseKDO 30.5 kDA, PlumKDO 31.8 kDa and BspeKDO 30.2 kDa. (B) Specific whole-cell biocatalyst activities, assays were performed in $0.5 \mathrm{~mL} 50 \mathrm{mM} \mathrm{KPi} \mathrm{pH} 7.4$ with $1 \mathrm{~g}_{\mathrm{CDW}} \mathrm{L}^{-1}, 10 \mathrm{mM}$ Lys, $20 \mathrm{mM} \alpha-\mathrm{KG}, 5 \mathrm{mM} \mathrm{L}(+)$-ascorbic acid and $1 \mathrm{mM} \mathrm{FeSO}_{4}$ for $1 \mathrm{~h}$ at $30{ }^{\circ} \mathrm{C}$ in an Eppendorf ${ }^{\circledR}$ ThermoMixer ${ }^{\circledR} \mathrm{C}$ at 500 rpm. n.d., not detected. Standard deviations are a result of two biological replicates.

Limitations due to mass transfer across the bacterial membrane have already been observed with whole-cell biocatalysts in combination with other $\mathrm{Fe}^{2+} / \alpha$-ketoglutaratedependent dioxygenases [25-27]. In these cases, permeabilization was achieved by Nymeen solution or freezing and thawing of the cells. Alternatively, the overexpression of respective transporters, for example LysP, the lysine permease from E. coli, could reduce mass transfer limitations. Such endeavors have already been proven successful for other whole-cell biocatalysts such as the production of 5-aminovalerate [28] or the production of L-pipecolic acid from Lys [29] using recombinant E. coli.

\subsection{Preparative-Scale Production of Hydroxy-L-Lysine}

We employed the most active biocatalyst, E. coli BL21 (DE3) pET-24a(+)-PlumKDO for the preparative production of $\mathrm{Hyl}$ on a $50 \mathrm{~mL}$ reaction scale (Figure 7). Using a biocatalyst concentration of $10 \mathrm{~g}_{\mathrm{CDW} \mathrm{L}} \mathrm{L}^{-1}$ (Figure 7A), $25 \mathrm{mM}$ of Lys were fully converted to Hyl. Motivated by these results, we set up a reaction with $50 \mathrm{mM}$ Lys. From $50 \mathrm{mM}$ initial Lys, $30 \mathrm{mM}$ were converted to Hyl during $12 \mathrm{~h}$ of biotransformation, which corresponds to a yield of ca. $60 \%$ and a titer of almost $5 \mathrm{~g} \mathrm{~L}^{-1}$ (Figure $7 \mathrm{~B}$ ). After $12 \mathrm{~h}$, no further conversion or degradation of the substrate and the product was observed. Generally, complete conversion of Lys to Hyl is feasible (Figure 7A). This was also demonstrated in studies with other KDOs $[4,7,8]$. Amatuni et al. fully converted approximately $40 \mathrm{mM}$ Lys to Hyl using a cell lysate from E. coli BL21 (DE3) expressing the gene coding for PbraKDO, with a final amount of lysate corresponding to an $\mathrm{OD}_{600}$ of 15 [8]. The reaction was carried out overnight at $23^{\circ} \mathrm{C}$ in $50 \mathrm{mM} \mathrm{KPi} \mathrm{pH} \mathrm{8.0.} \mathrm{In} \mathrm{our} \mathrm{study,} \mathrm{we} \mathrm{employed} \mathrm{cells} \mathrm{at} \mathrm{an} \mathrm{OD}_{600}$ of 30 at $30^{\circ} \mathrm{C}$ in $50 \mathrm{mM} \mathrm{KPi} \mathrm{pH} \mathrm{7.4.} \mathrm{It} \mathrm{is} \mathrm{therefore} \mathrm{very} \mathrm{likely} \mathrm{that} \mathrm{optimization} \mathrm{of} \mathrm{the} \mathrm{reaction} \mathrm{conditions}$ may lead to a higher degree of conversion. Moreover, the use of Triton X-100 may not fully circumvent mass transfer limitation in the whole-cell biotransformation. 
A

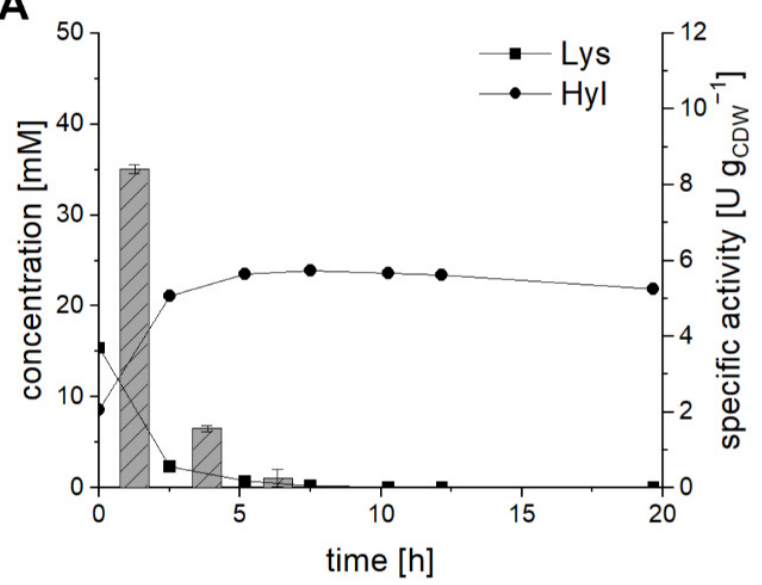

B

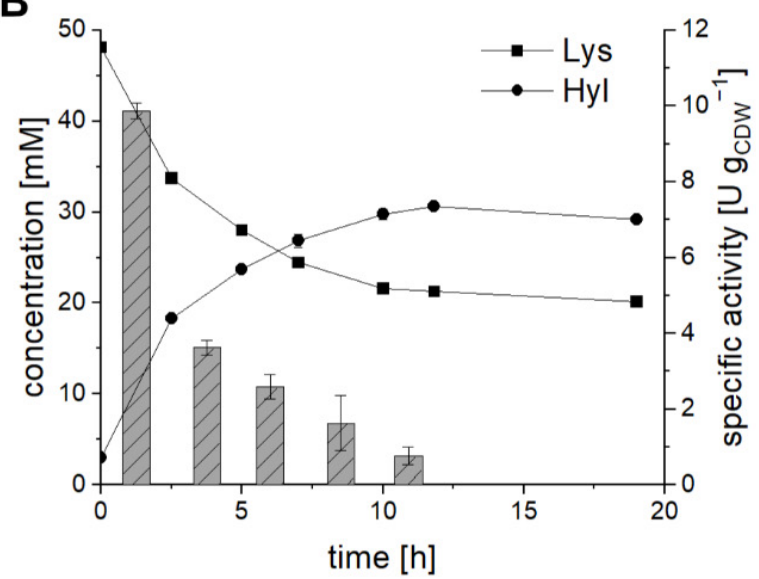

Figure 7. Progress curve of the whole-cell biotransformation on a preparative scale with E. coli BL21 (DE) pET-24a(+)PlumKDO; (A) 25 mM Lys (initial concentration), (B) $50 \mathrm{mM}$ Lys (initial concentration). Specific activities were calculated from the respective product concentrations between the sampling times. Biotransformation was performed in $50 \mathrm{~mL}$ at $30{ }^{\circ} \mathrm{C}$ and $180 \mathrm{rpm}$. The reaction mixture contained $10 \mathrm{~g}_{\mathrm{CDW}} \mathrm{L}^{-1}$ cells in $50 \mathrm{mM} \mathrm{KPi}$ buffer $\mathrm{pH}$ 7.4. Error bars are a result of technical duplicates.

The activity during the first $2.5 \mathrm{~h}$ is in the same range as in the small-scale biotransformations, which reflects the principal scalability (Figure 7). While the specific activity during the first $2.5 \mathrm{~h}$ of reaction is about $10 \mathrm{U} \mathrm{g}_{\mathrm{CDW}}{ }^{-1}$ for the biotransformation with initially $50 \mathrm{mM}$ Lys, it already drops to $3.6 \mathrm{U} \mathrm{gCDW}^{-1}$ between 2.5 and $5 \mathrm{~h}$ (Figure 7B). As $\alpha-K G$ was added in large excess (twofold concentration of Lys), this is not likely to be the reason for the incomplete conversion. The $\mathrm{K}_{\mathrm{M}}$ of PbraKDO is about $34 \mu \mathrm{M}$ for Lys, so the decreasing substrate concentration is not considered to be the reason for the reduction in the specific activity in the reaction with $50 \mathrm{mM}$ initial Lys [9]. Product inhibition might be an explanation but has not yet been reported for KDOs. The incomplete conversion might also be attributed to enzyme stability (kinetic stability, thermodynamic stability, operational stability). Moreover, $\mathrm{Fe}^{2+} / \alpha$-ketoglutarate-dependent dioxygenases are reported to show uncoupling effects, which might lead to inactivation of the biocatalyst and therefore result in incomplete conversion [30]. Interestingly, Hara et al. were able to completely convert up to $600 \mathrm{mM}$ Lys to Hyl, with E. coli whole-cell biocatalysts expressing the gene coding for $\mathrm{KradKDO}$ (K4H-1 in their study) using a biocatalyst concentration of $\mathrm{OD}_{600}=30$ in $52 \mathrm{~h}$ [4]. This might indicate higher biocatalyst stability, which is of high importance for efficient scale-up. The reasons for this significantly higher stability are not yet known. Nevertheless, our results are a good basis and they demonstrate the principal applicability of the wholecell biocatalyst, which already showed suitable productivity and a high titer without a detailed optimization. Through optimization of the reaction parameters and systematic elucidation of the process boundaries, the overall performance of the biotransformation can likely be further increased [31].

\section{Materials and Methods}

\subsection{Chemicals/Strains and Plasmids}

Chemicals were purchased from Carl Roth GmbH \& Co. KG (Karlsruhe, Germany), VWR International (Radnor, PA, USA), Merck KGaA (Darmstadt, Germany), Sigma-Aldrich Chemie GmbH (Steinheim, Germany), AppliChem GmbH (Darmstadt, Germany) and Thermo Fisher Scientific (Waltham, MA, USA). The kits for DNA extraction (NucleoSpin ${ }^{\circledR}$ Gel and PCR Clean-up), plasmid isolation (NucleoSpin ${ }^{\circledR}$ Plasmid (No Lid)) and genomic DNA extraction (NucleoSpin ${ }^{\circledR}$ Microbial DNA) were purchased from Macherey-Nagel GmbH \& CO. KG (Düren, Germany). Q5 ${ }^{\circledR}$ High-Fidelity Polymerase (2× Master Mix) and restriction enzymes were purchased from New England Biolabs (Ipswich, MA, USA). Plasmids pG-KJE8, pTf16, pGro7, pG-Tf2, and pKJE7 were obtained from Takara Holdings 
Inc. (Kyoto, Japan). The plasmids pET-22b(+)-CaciKDO, pET-22b(+)-CpinKDO, and pET$22 \mathrm{~b}(+)-$-FjohKDO were a kind gift from Prof. Anne Zaparucha and were described in [3].

A list of strains and plasmids used in this study is shown in Table 2. Nucleotide sequences of the genes are provided in Supplementary Materials (Table S2).

\subsection{Cloning}

Gene sequences coding for KradKDO and KrhiKDO were amplified from genomic DNA of Kineococcus radiotolerans and Kineococcus rhizosphearae with the primer pairs PPN070/PPN071 and PPN072/PPN073 and cloned into NdeI/NotI digested pET-24a(+) via Gibson cloning. Gene sequences coding for PbraKDO (PPN088/PPN089), BplaKDO (PPN091/PPN092), PlumKDO (PPN092/PPN093), BpseKDO (PPN094/PPN095), BspeKDO (PPN096/PPN097) and MintKDO (PPN074/PPN075) were purchased as DNA strings from Thermo Fisher Scientific (Waltham, MA, USA) and amplified by PCR with the indicated primer pairs. The PCR products were purified by gel electrophoresis and cloned into NdeI/NotI digested pET-24a(+) via Gibson cloning [32]. The codon-optimized gene sequence of PbraKDO was adopted from [9], gene sequences of the homologs were codonoptimized for E. coli by Thermo Fisher Scientific.

Table 2. Strains and plasmids used in this study.

\begin{tabular}{|c|c|c|c|}
\hline Strain & \multicolumn{3}{|c|}{ Information } \\
\hline Escherichia coli $\mathrm{DH} 5 \alpha$ & \multicolumn{3}{|c|}{$\begin{array}{c}\text { F-, } \Phi 80 \text { dlacZ } \Delta \text { M15, } \Delta(\text { lacZYA-argF)U169, deoR, recA1, endA1, } \\
\text { hsdR17(rK-mK+), phoA, supE44, } \lambda-\text {, thi } 1, \text { gyrA96, relA1 }\end{array}$} \\
\hline Escherichia coli BL21 (DE3) & \multicolumn{3}{|c|}{ F-, ompT, hsdSB(rB-mB-), gal (c1875, ind1, Sam7, nin5, lacUV5-T7 gene1), dcm (DE3) } \\
\hline Kineococcus radiotolerans & \multicolumn{3}{|c|}{ wild-type, DSM No. 14245} \\
\hline Kineococcus rhizospharae & \multicolumn{3}{|c|}{ wild-type, DSM No. 19711} \\
\hline Plasmid & Protein & Description & Reference \\
\hline $\mathrm{pET}-22 \mathrm{~b}(+)-\mathrm{CaciKDO}$ & CaciKDO & KDO, L-Lysine 3-hydroxylase & [3] \\
\hline pET-22b(+)-CpinKDO & CpinKDO & KDO, L-Lysine 4-hydroxylase & [3] \\
\hline pET-22b(+)-FjohKDO & FjohKDO & KDO, L-Lysine 4-hydroxylase & [3] \\
\hline pET-22b(+)-NkorKDO & NkorKDO & KDO, L-Lysine 4-hydroxylase & [3] \\
\hline pET-22b(+)-FspeKDO & FspeKDO & KDO, L-Lysine 4-hydroxylase & [3] \\
\hline pET-24a(+)-KradKDO & KradKDO & KDO, L-Lysine 3-hydroxylase & This study \\
\hline pET-24a(+)-KrhiKDO & KrhiKDO & Putative KDO & This study \\
\hline pET-24a(+)-MintKDO & MintKDO & Putative KDO & This study \\
\hline pET-24a(+)-PbraKDO & PbraKDO & KDO, L-Lysine 4-hydroxylase & This study \\
\hline pET-24a(+)-BplaKDO & BplaKDO & Putative KDO & This study \\
\hline pET-24a(+)-BpseKDO & BpseKDO & Putative KDO & This study \\
\hline pET-24a(+)-PlumKDO & PlumKDO & Putative KDO & This study \\
\hline pET-24a(+)-BspeKDO & BspeKDO & Putative KDO & This study \\
\hline pAR1219 & T7RNAP & T7 RNA-polymerase & [33] \\
\hline pG-KJE8 & $\begin{array}{l}\text { DnaK, DnaJ, GrpE, GroES, } \\
\text { GroEL }\end{array}$ & Molecular chaperones & [24] \\
\hline pKJE7 & DnaK, DnaJ, GrpE & Molecular chaperones & [24] \\
\hline pGro7 & GroES, GroEL & Molecular chaperones & [24] \\
\hline pG-Tf2 & GroES, GroEL, tig & Molecular chaperones & [34] \\
\hline pTf16 & tig & Molecular chaperones & [34] \\
\hline
\end{tabular}

All vector constructs were checked for errors with sanger sequencing (Microsynth Seqlab, Göttingen, Germany). Plasmids used in this study are shown in Table 2 and nucleotide sequences of the genes and primers are provided in the Supplementary Materials (Tables S1 and S2).

\subsection{E. coli Extract Preparation}

The E. coli extract was prepared as described by [15] with some modifications, which are stated in the following. E. coli BL21 (DE3) was transformed with pAR1219 for overexpression of T7 RNA polymerase (T7RNAP) and with pG-KJE8, pKJE7, pGro7, pG-Tf2, 
or pTf16 for the overexpression of different chaperone sets, respectively. A preculture of $10 \mathrm{~mL}$ lysogeny broth medium (LB, $10 \mathrm{~g} \mathrm{~L}^{-1}$ tryptone, $5 \mathrm{~g} \mathrm{~L}^{-1}$ yeast extract, $5 \mathrm{~g} \mathrm{~L}^{-1} \mathrm{NaCl}$ ) with $100 \mu \mathrm{g} \mathrm{mL}^{-1}$ ampicillin and $20 \mu \mathrm{g} \mathrm{mL}^{-1}$ chloramphenicol, in case of strains with chaperone-encoding plasmids, was inoculated with a single colony of the source strain for the cell extract. The preculture was grown for $16 \mathrm{~h}$ at $200 \mathrm{rpm}$ and $37^{\circ} \mathrm{C}$. The main culture of $125 \mathrm{~mL} 2$ xYTPG medium $\left(16 \mathrm{~g} \mathrm{~L}^{-1}\right.$ tryptone, $10 \mathrm{~g} \mathrm{~L}^{-1}$ yeast extract, $5 \mathrm{~g} \mathrm{~L}^{-1} \mathrm{NaCl}$, $7 \mathrm{~g} \mathrm{~L}^{-1} \mathrm{~K}_{2} \mathrm{HPO}_{4}, 3 \mathrm{~g} \mathrm{~L}^{-1} \mathrm{KH}_{2} \mathrm{PO}_{4}, 18 \mathrm{~g} \mathrm{~L}^{-1}$ glucose) in a $1 \mathrm{~L}$ baffled shake flask was inoculated to an $\mathrm{OD}_{600}$ of 0.1 and grown at $200 \mathrm{rpm}$ at $37^{\circ} \mathrm{C}$. Chaperone expression was induced by addition of $0.5 \mathrm{mg} \mathrm{mL}^{-1}$ L-arabinose (Carl Roth, Karlsruhe, Germany) or $5 \mathrm{ng} \mathrm{mL}^{-1}$ tetracycline (Thermo Fisher Scientific, Waltham, MA, USA) according to the manual of the chaperone plasmid set. At an $\mathrm{OD}_{600}$ of $0.6,1 \mathrm{mM}$ of isopropyl- $\beta$-D-thiogalactopyranoside (IPTG, Carl Roth, Karlsruhe, Germany) was added to induce T7RNAP production. Cells were harvested at an $\mathrm{OD}_{600}$ of 3 and pelleted via centrifugation at $5000 \times g$ for $10 \mathrm{~min}$ at $10^{\circ} \mathrm{C}$. The pellets were washed three times with $4{ }^{\circ} \mathrm{C}$ cold S30 buffer $(10 \mathrm{mM}$ tris acetate, $\mathrm{pH}$ 8.2; $14 \mathrm{mM}$ magnesium acetate; $60 \mathrm{mM}$ potassium acetate; and $2 \mathrm{mM}$ dithiothreitol (DTT, Carl Roth, Karlsruhe, Germany), flash-frozen with liquid nitrogen, and stored at $-80{ }^{\circ} \mathrm{C}$. For lysis, cells were thawed on ice and resuspended in $1 \mathrm{~mL}$ of $\mathrm{S} 30$ buffer per gram of wet cells. Three cycles of sonication were performed for $40 \mathrm{~s}$ and $2 \mathrm{mM}$ DTT were added. Cellular debris was removed by centrifugation at $18,000 \times \mathrm{g}$ for $10 \mathrm{~min}$ at $4{ }^{\circ} \mathrm{C}$. The supernatant was incubated in an Eppendorf ${ }^{\circledR}$ ThermoMixer ${ }^{\circledR} \mathrm{C}$ (Eppendorf, Hamburg, Germany) at $450 \mathrm{rpm}$ for $60 \mathrm{~min}$ at $37^{\circ} \mathrm{C}$, and then centrifuged at $10,000 \times g$ for $10 \mathrm{~min}$ at $4{ }^{\circ} \mathrm{C}$. The final supernatant was flash-frozen with liquid nitrogen and stored at $-80^{\circ} \mathrm{C}$ until use. Protein concentrations were determined by the Bradford method using bovine serum albumin (BSA) as a standard [35]. Obtained extracts contained between 40 and $60 \mathrm{mg} \mathrm{mL}^{-1}$ total protein.

\subsection{Cell-Free Protein Synthesis (CFPS)}

CFPS reactions with a reaction volume of $20 \mu \mathrm{L}$ were performed in microtubes containing: E. coli cell free extract (see 4.3 ) amounting to 9.2 to $15.3 \mathrm{mg} \mathrm{mL}^{-1}$ protein, $10 \mathrm{mM}$ magnesium glutamate, $130 \mathrm{mM}$ potassium glutamate, $1.5 \mathrm{mM}$ each of 20 amino acids (except leucine), $1.25 \mathrm{mM}$ leucine, $50 \mathrm{mM}$ 4-(2-hydroxyethyl)-1-piperazineethanesulfonic acid (HEPES), $1.5 \mathrm{mM}$ ATP and GTP, $0.9 \mathrm{mM}$ cytidine triphosphate (CTP) and uridine triphosphate (UTP), $0.2 \mathrm{mg} \mathrm{mL}^{-1}$ E. coli tRNA, $0.26 \mathrm{mM}$ coenzyme A (CoA), $0.33 \mathrm{mM}$ nicotinamide adenine dinucleotide (NAD), $0.75 \mathrm{mM}$ cyclic adenosine monophosphate (cAMP), $0.068 \mathrm{mM}$ folinic acid, $1 \mathrm{mM}$ spermidine, $30 \mathrm{mM}$ 3-phosphoglyceric acid (3-PGA), $2 \%$ polyethylene glycol-8000 (PEG), and $5 \mathrm{nM}$ plasmid DNA. Reactions were incubated in an Eppendorf ${ }^{\circledR}$ ThermoMixer ${ }^{\circledR} \mathrm{C}$ for $4 \mathrm{~h}$ at $450 \mathrm{rpm}$ and $37^{\circ} \mathrm{C}$.

\subsection{In Vitro Biotransformations}

In vitro biotransformation reactions were performed in a total volume of $100 \mu \mathrm{L}$, consisting of $20 \mu \mathrm{L}$ CFPS-reaction solution and $80 \mu \mathrm{L}$ assay solution (50 mM KPi pH 7.0). Final concentrations were $10 \mathrm{mM}$ Lys, $20 \mathrm{mM} \alpha-\mathrm{KG}, 5 \mathrm{mM} \mathrm{L}(+)$-ascorbic acid, and $1 \mathrm{mM}$ $\mathrm{FeSO}_{4}$. Reactions were incubated in $1.5 \mathrm{~mL}$ reaction tubes at $25^{\circ} \mathrm{C}$ and $500 \mathrm{rpm}$ in an Eppendorf $^{\circledR}$ ThermoMixer ${ }^{\circledR} \mathrm{C}$ for $20 \mathrm{~h}$ and stopped by addition of $100 \mu \mathrm{L}$ acetonitrile. After centrifugation for $10 \mathrm{~min}$ and $17,000 \times g$, the supernatant was subjected to LC-MS analysis.

\subsection{Resting-Cell Biotransformations}

For resting-cell biotransformations, LB pre-cultures $(10 \mathrm{~mL})$ were inoculated from cryogenic-stocks and incubated at $37^{\circ} \mathrm{C}$ and $200 \mathrm{rpm}$ overnight. A $50 \mathrm{~mL}$ LB culture with $50 \mu \mathrm{g} \mathrm{mL}^{-1}$ kanamycin was inoculated to an initial $\mathrm{OD}_{600}$ of 0.1 and incubated at $37^{\circ} \mathrm{C}$ and $200 \mathrm{rpm}$ until an $\mathrm{OD}_{600}$ of $0.6-0.8$. Cultures were then cooled on ice for $20 \mathrm{~min}$ and heterologous gene expression was started by addition of $0.5 \mathrm{mM}$ IPTG. Cultivation was continued at $20^{\circ} \mathrm{C}$ for another $20 \mathrm{~h}$. 
Cells were harvested by centrifugation $\left(4500 \times g, 10 \mathrm{~min}, 4{ }^{\circ} \mathrm{C}\right)$ and resuspended in $50 \mathrm{mM} \mathrm{KPi}$ buffer $\mathrm{pH} 7.4$ to a biomass concentration of approximately $1 \mathrm{~g}_{\mathrm{CDW} \mathrm{L}} \mathrm{L}^{-1}$ (an $\mathrm{OD}_{600}$ of 1 corresponds to $0.312 \mathrm{~g}_{\mathrm{CDW}} \mathrm{L}^{-1}$ ). Resting-cell biotransformations were performed in a total volume of $0.5 \mathrm{~mL}$ in $2 \mathrm{~mL}$ reaction tubes $\left(1 \mathrm{~g}_{\mathrm{CDW}} \mathrm{L}^{-1}, 20 \mathrm{mM} \alpha-\mathrm{KG}\right.$, $5 \mathrm{mM} \mathrm{L}(+)$-ascorbic acid and $\left.1 \mathrm{mM} \mathrm{FeSO}_{4}\right)$. Reactions were performed at $30^{\circ} \mathrm{C}$ and $500 \mathrm{rpm}$ in an Eppendorf ${ }^{\circledR}$ ThermoMixer ${ }^{\circledR}$ C. After preconditioning for $5 \mathrm{~min}$, biotransformation was started by addition of $10 \mathrm{mM}$ Lys and the reactions were incubated for $60 \mathrm{~min}$ and quenched by addition of $0.5 \mathrm{~mL}$ acetonitrile. Following centrifugation for $10 \mathrm{~min}$ and $17,000 \times g$, the supernatant was analyzed via LC-MS.

\subsection{Preparative-Scale Biotransformation}

For the preparative-scale biotransformation, E. coli BL21 (DE3) pET-24a(+)-PlumKDO was cultivated as in 3.6, but the main cultures consisted of $2 \times 200 \mathrm{~mL}$ LB medium in 2-L baffled shake flasks. After cultivation, the cells were harvested by centrifugation and concentrated to the desired biomass concentration. The biotransformation was performed in a volume of $50 \mathrm{~mL}$ at $30^{\circ} \mathrm{C}$ and with orbital shaking at $180 \mathrm{rpm}(2.5 \mathrm{~cm}$ amplitude $)$ in a $500 \mathrm{~mL}$ baffled shake flask. The reaction mixture contained 50 or $100 \mathrm{mM} \alpha-\mathrm{KG}$ (twofold concentration of Lys), $5 \mathrm{mM} \mathrm{FeSO}_{4}, 10 \mathrm{mM} \mathrm{L}(+)$-ascorbic acid, 1\% v/v Triton $\mathrm{X}-100$ and approximately $10 \mathrm{~g}_{\mathrm{CDW}} \mathrm{L}^{-1}$ cells in $50 \mathrm{mM} \mathrm{KPi}$ buffer $\mathrm{pH}$ 7.4. The cells were preconditioned at the desired temperature for $10 \mathrm{~min}$. Afterwards, the reaction was started by addition of 25 or $50 \mathrm{mM}$ Lys. Aliquots of $0.5 \mathrm{~mL}$ were withdrawn after regular time intervals and cells were separated by centrifugation $(10 \mathrm{~min}, 17,000 \times g)$ and the supernatant was subjected to LC-MS analysis.

\subsection{Analytics}

Detection and quantification of Lys and Hyl was performed on an Agilent 1260 Infinity II liquid chromatography system coupled to a 6120 single quadrupole ESI mass spectrometer (Agilent Technologies Inc., Santa Clara, CA, USA). Chromatographic separation was realized with an iHILIC $^{\circledR}-(\mathrm{P})$ Classic column $(150 \times 2.1 \mathrm{~mm}, 5 \mu \mathrm{m}, 200 \AA)$ in combination with a SeQuant ${ }^{\circledR} \mathrm{ZIC}^{\circledR}$-pHILIC-guard column $(20 \times 2.1 \mathrm{~mm}, 5 \mu \mathrm{m}, 200 \AA)$ in isocratic mode (70\% acetonitrile, $30 \% 50 \mathrm{mM}$ ammonium acetate $\mathrm{pH} 4.0$ ) and a flow rate of $0.2 \mathrm{~mL} \mathrm{~min}^{-1}$ in 20 min. MS-analysis was conducted in positive SIM mode with the following settings: drying gas chamber temperature $350{ }^{\circ} \mathrm{C}$, gas flow $12 \mathrm{~L} \mathrm{~min}^{-1}$, capillary voltage $3000 \mathrm{~V}$ and nebulizer pressure 35 psig. Quantification was conducted by external calibration using standards of Lys (Sigma-Aldrich, St. Louis, MI, USA) and 5-hydroxy-DL-lysine hydrochloride (Carbosynth, Compton, $\mathrm{UK}$ ) as the latter was the only commercially available Hyl isomer. Lys was retrieved as $[\mathrm{M}+\mathrm{H}]^{+}\left(m / z\right.$ 147.1) and Hyl isomers as $[\mathrm{M}+\mathrm{H}]^{+}(m / z$ 163.1).

\section{Conclusions}

In this study, CFPS has been combined with subsequent activity assays for the identification of $\mathrm{Fe}^{2+} / \alpha$-ketoglutarate-dependent dioxygenases for the first time. Investigating a set of known and putative KDOs, production of Hyl was confirmed for all published as well as for new, previously undescribed enzymes. This demonstrates that CFPS is a valuable tool to simplify and speed up the identification of new $\mathrm{Fe}^{2+} / \alpha$-ketoglutarate-dependent dioxygenases. In current research, for example, genetic-engineering derived enzyme variants are generated, which possess higher activity or which expand the reaction and substrate scope of $\mathrm{Fe}^{2+} / \alpha$-ketoglutarate-dependent dioxygenases [5,36-38]. It is reasonable that our screening system would also allow for rapid prototyping of enzyme variants, analysis of the substrate scope, or the screening of different reaction conditions. With regard to our study, it will be interesting to investigate the substrate scope of our newly identified enzymes as PbraKDO also accepts L-leucine and L-methionine as substrates [9].

We successfully applied the newly identified KDOs in a whole-cell biocatalyst format. Mass transfer of the substrates and products across the membrane was found to be a major limitation of the biotransformation. Using a permeabilization method with Triton X-100, 
preparative-scale production of $\mathrm{Hyl}$ was accomplished and feasibility was demonstrated. Reaction conditions ( $\mathrm{pH}$, temperature) and enzyme stabilities require further investigation and optimization, which would very likely lead to higher product formation. Optimization of gene expression (IPTG concentration and expression temperature) may lead to higher percentages of functionally active protein, which in turn is expected to yield higher reaction rates and conversion. Moreover, our experiments with CFPS and different combinations of chaperones indicate that distinct sets of chaperones (e.g., DnaK, DnaJ, GrpE, GroES, and GroEL in the case of PbraKDO and its homologs) might be beneficial for biocatalyst activity also in a whole-cell format. While some chaperones and combinations thereof had a beneficial influence on product formation, others showed severe detrimental effects. This demonstrates the applicability of CFPS for the screening of chaperones for difficult-toexpress proteins.

In summary, a systematic approach from CFPS to screen and identify novel $\mathrm{Fe}^{2+} / \alpha-$ ketoglutarate-dependent dioxygenases to a whole-cell biotransformation for the preparative synthesis of Hyl was successfully developed. New homologs have now been identified with suitable reactivity, resulting in a multi-gram scale hydroxylation reaction. These homologs now expand the spectrum of the previously limited number of described KDOs (nine wild-type enzymes) and represent potential new candidates for biotechnological application.

Supplementary Materials: The following are available online at https:/ /www.mdpi.com/article/ 10.3390 / catal11091038/s1, Figure S1. Exemplary plasmid map of pET-22b(+)-CaciKDO, Figure S2. Exemplary plasmid map of pET-24a(+)-PbraKDO, Figure S3-S26 SDS-PAGE analysis of cell-free synthesized KDOs (with and without chaperone-enriched extracts), Table S1. Primer sequences, Table S2. Gene sequences, Table S3. Amino acid sequences.

Author Contributions: Conceptualization, J.R., P.N., S.L. and K.R.; methodology, J.R., P.N., S.L. and K.R.; formal analysis, J.R., P.N., A.B. and S.K.; investigation, J.R., P.N., A.B. and S.K.; resources, S.L.; data curation, S.L. and K.R.; writing-original draft preparation, J.R., P.N. and K.R.; writingreview and editing, S.L. and K.R.; visualization, J.R. and P.N.; supervision, S.L. and K.R.; project administration, S.L. and K.R.; funding acquisition, S.L. All authors have read and agreed to the published version of the manuscript.

Funding: This research was supported by the CLIB-Competence Center Biotechnology (CKB) funded by the European Regional Development Fund (EFRE) and the North-Rhine Westphalian Ministry of Economic Affairs, Innovation, Digitalization and Energy (MWIDE). (Grant number: EFRE-0300098).

Data Availability Statement: Data is contained within the article or supplementary material.

Acknowledgments: We thank Markus Nett, Martina Pohl, and Selina Seide for scientific advice and fruitful discussions. The plasmids pET-22b(+)-CaciKDO, pET-22b(+)-CpinKDO, and pET-22b(+)FjohKDO were a kind gift from Anne Zaparucha. We would like to acknowledge the support with LC-MS analytics by Chantale Zammarelli.

Conflicts of Interest: The authors declare no conflict of interest. The funders had no role in the design of the study; in the collection, analyses, or interpretation of data; in the writing of the manuscript, or in the decision to publish the results.

\section{References}

1. Peters, C.; Buller, R. Industrial Application of 2-Oxoglutarate-Dependent Oxygenases. Catalysts 2019, 9, 221. [CrossRef]

2. Herr, C.Q.; Hausinger, R.P. Amazing Diversity in Biochemical Roles of Fe(II)/2-Oxoglutarate Oxygenases. Trends Biochem. Sci. 2018, 43, 517-532. [CrossRef]

3. Baud, D.; Saaidi, P.-L.; Monfleur, A.; Harari, M.; Cuccaro, J.; Fossey, A.; Besnard, M.; Debard, A.; Mariage, A.; Pellouin, V.; et al. Synthesis of Mono- and Dihydroxylated Amino Acids with New $\alpha$-Ketoglutarate-Dependent Dioxygenases: Biocatalytic Oxidation of C-H Bonds. ChemCatChem 2014, 6, 3012-3017. [CrossRef]

4. Hara, R.; Yamagata, K.; Miyake, R.; Kawabata, H.; Uehara, H.; Kino, K. Discovery of Lysine Hydroxylases in the Clavaminic Acid Synthase-Like Superfamily for Efficient Hydroxylysine Bioproduction. Appl. Environ. Microbiol. 2017, 83, e00693-17. [CrossRef]

5. Wang, F.; Zhu, M.; Song, Z.; Li, C.; Wang, Y.; Zhu, Z.; Sun, D.; Lu, F.; Qin, H.-M. Reshaping the Binding Pocket of Lysine Hydroxylase for Enhanced Activity. ACS Catal. 2020, 10, 13946-13956. [CrossRef] 
6. Marin, J.; Didierjean, C.; Aubry, A.; Casimir, J.R.; Briand, J.P.; Guichard, G. Synthesis of Enantiopure 4-Hydroxypipecolate and 4-Hydroxylysine Derivatives from a Common 4,6-Dioxopiperidinecarboxylate Precursor. J. Org. Chem. 2004, 69, 130-141. [CrossRef]

7. Zhang, X.; King-Smith, E.; Renata, H. Total Synthesis of Tambromycin by Combining Chemocatalytic and Biocatalytic C-H Functionalization. Angew. Chem. Int. Ed. 2018, 57, 5037-5041. [CrossRef]

8. Amatuni, A.; Shuster, A.; Adibekian, A.; Renata, H. Concise Chemoenzymatic Total Synthesis and Identification of Cellular Targets of Cepafungin I. Cell Chem. Biol. 2020, 27, 1318-1326.e18. [CrossRef] [PubMed]

9. Amatuni, A.; Renata, H. Identification of a Lysine 4-Hydroxylase from the Glidobactin Biosynthesis and Evaluation of Its Biocatalytic Potential. Org. Biomol. Chem. 2019, 17, 1736-1739. [CrossRef] [PubMed]

10. Baud, D.; Peruch, O.; Saaidi, P.-L.; Fossey, A.; Mariage, A.; Petit, J.-L.; Salanoubat, M.; Vergne-Vaxelaire, C.; de Berardinis, V.; Zaparucha, A. Biocatalytic Approaches towards the Synthesis of Chiral Amino Alcohols from Lysine: Cascade Reactions Combining Alpha-Keto Acid Oxygenase Hydroxylation with Pyridoxal Phosphate- Dependent Decarboxylation. Adv. Synth. Catal. 2017, 359, 1563-1569. [CrossRef]

11. Fossey-Jouenne, A.; Vergne-Vaxelaire, C.; Zaparucha, A. Enzymatic Cascade Reactions for the Synthesis of Chiral Amino Alcohols from L-Lysine. J. Vis. Exp. 2018, 132, 56926. [CrossRef] [PubMed]

12. Rolf, J.; Rosenthal, K.; Lütz, S. Application of Cell-Free Protein Synthesis for Faster Biocatalyst Development. Catalysts 2019, 9 , 190. [CrossRef]

13. Quertinmont, L.T.; Orru, R.; Lutz, S. RApid Parallel Protein EvaluatoR (RAPPER), from Gene to Enzyme Function in One Day. Chem. Commun. 2015, 51, 122-124. [CrossRef] [PubMed]

14. Silverman, A.D.; Karim, A.S.; Jewett, M.C. Cell-Free Gene Expression: An Expanded Repertoire of Applications. Nat. Rev. Genet. 2020, 21, 151-170. [CrossRef]

15. Rolf, J.; Siedentop, R.; Lütz, S.; Rosenthal, K. Screening and Identification of Novel CGAS Homologues Using a Combination of in Vitro and In Vivo Protein Synthesis. Int. J. Mol. Sci. 2019, 21, 105. [CrossRef]

16. Stech, M.; Kubick, S. Cell-Free Synthesis Meets Antibody Production: A Review. Antibodies 2015, 4, 12-33. [CrossRef]

17. Kang, S.-H.; Kim, D.-M.; Kim, H.-J.; Jun, S.-Y.; Lee, K.-Y.; Kim, H.-J. Cell-Free Production of Aggregation-Prone Proteins in Soluble and Active Forms. Biotechnol. Prog. 2005, 21, 1412-1419. [CrossRef] [PubMed]

18. Yang, H.-J.; Lee, K.-H.; Lim, H.J.; Kim, D.-M. Tandem Cell-Free Protein Synthesis as a Tool for Rapid Screening of Optimal Molecular Chaperones. Biotechnol. J. 2019, 14, 1800523. [CrossRef] [PubMed]

19. Bastard, K.; Isabet, T.; Stura, E.A.; Legrand, P.; Zaparucha, A. Structural Studies Based on Two Lysine Dioxygenases with Distinct Regioselectivity Brings Insights Into Enzyme Specificity within the Clavaminate Synthase-Like Family. Sci. Rep. 2018, 8, 8-18. [CrossRef] [PubMed]

20. Madeira, F.; Park, Y.M.; Lee, J.; Buso, N.; Gur, T.; Madhusoodanan, N.; Basutkar, P.; Tivey, A.R.N.; Potter, S.C.; Finn, R.D.; et al. The EMBL-EBI Search and Sequence Analysis Tools APIs in 2019. Nucleic Acids Res. 2019, 47, W636-W641. [CrossRef]

21. Tang, B.; Yu, Y.; Liang, J.; Zhang, Y.; Bian, X.; Zhi, X.; Ding, X. Reclassification of 'Polyangium Brachysporum' DSM 7029 as Schlegelella Brevitalea Sp. Nov. Int. J. Syst. Evol. Microbiol. 2019, 69, 2877-2883. [CrossRef] [PubMed]

22. Koehntop, K.D.; Emerson, J.P.; Que, L. The 2-His-1-Carboxylate Facial Triad: A Versatile Platform for Dioxygen Activation by Mononuclear Non-Heme Iron(II) Enzymes. J. Biol. Inorg. Chem. 2005, 10, 87-93. [CrossRef] [PubMed]

23. Schinn, S.M.; Broadbent, A.; Bradley, W.T.; Bundy, B.C. Protein Synthesis Directly from PCR: Progress and Applications of Cell-Free Protein Synthesis with Linear DNA. N. Biotechnol. 2016, 33, 480-487. [CrossRef] [PubMed]

24. Nishihara, K.; Kanemori, M.; Kitagawa, M.; Yanagi, H.; Yura, T. Chaperone Coexpression Plasmids: Differential and Synergistic Roles of DnaK-DnaJ-GrpE and GroEL-GroES in Assisting Folding of an Allergen of Japanese Cedar Pollen, Cryj2, in Escherichia Coli. Appl. Environ. Microbiol. 1998, 64, 1694-1699. [CrossRef]

25. Falcioni, F.; Blank, L.M.; Frick, O.; Karau, A.; Bühler, B.; Schmida, A. Proline Availability Regulates Proline-4-Hydroxylase Synthesis and Substrate Uptake in Proline-Hydroxylating Recombinant Escherichia Coli. Appl. Environ. Microbiol. 2013, 79, 3091-3100. [CrossRef]

26. Hara, R.; Nishikawa, T.; Okuhara, T.; Koketsu, K.; Kino, K. Ectoine Hydroxylase Displays Selective Trans-3-Hydroxylation Activity towards 1-Proline. Appl. Microbiol. Biotechnol. 2019, 103, 5689-5698. [CrossRef]

27. Zhang, C.; Ma, J.; Li, Z.; Liang, Y.; Xu, Q.; Xie, X.; Chen, N. A Strategy for L-Isoleucine Dioxygenase Screening and 4Hydroxyisoleucine Production by Resting Cells. Bioengineered 2017, 9, 72-79. [CrossRef]

28. Li, Z.; Xu, J.; Jiang, T.; Ge, Y.; Liu, P.; Zhang, M.; Su, Z.; Gao, C.; Ma, C.; Xu, P. Overexpression of Transport Proteins Improves the Production of 5-Aminovalerate from 1-Lysine in Escherichia Coli. Sci. Rep. 2016, 6, 30884. [CrossRef]

29. Cheng, J.; Huang, Y.; Mi, L.; Chen, W.; Wang, D.; Wang, Q. An Economically and Environmentally Acceptable Synthesis of Chiral Drug Intermediate L-Pipecolic Acid from Biomass-Derived Lysine via Artificially Engineered Microbes. J. Ind. Microbiol. Biotechnol. 2018, 45, 405-415. [CrossRef]

30. Mantri, M.; Zhang, Z.; McDonough, M.A.; Schofield, C.J. Autocatalysed Oxidative Modifications to 2-Oxoglutarate Dependent Oxygenases. FEBS J. 2012, 279, 1563-1575. [CrossRef]

31. Kadisch, M.; Willrodt, C.; Hillen, M.; Bühler, B.; Schmid, A. Maximizing the Stability of Metabolic Engineering-Derived Whole-Cell Biocatalysts. Biotechnol. J. 2017, 12, 1600170. [CrossRef] 
32. Gibson, D.G.; Young, L.; Chuang, R.-Y.; Venter, J.C.; Hutchison, C.A.; Smith, H.O. Enzymatic Assembly of DNA Molecules up to Several Hundred Kilobases. Nat. Methods 2009, 6, 343-345. [CrossRef]

33. Davanloo, P.; Rosenberg, A.H.; Dunn, J.J.; Studier, F.W. Cloning and Expression of the Gene for Bacteriophage T7 RNA Polymerase. Proc. Natl. Acad. Sci. USA 1984, 81, 2035-2039. [CrossRef]

34. Nishihara, K.; Kanemori, M.; Yanagi, H.; Yura, T. Overexpression of Trigger Factor Prevents Aggregation of Recombinant Proteins in Escherichia Coli. Appl. Environ. Microbiol. 2000, 66, 884-889. [CrossRef] [PubMed]

35. Bradford, M.M. A Rapid and Sensitive Method for the Quantitation of Microgram Quantities of Protein Utilizing the Principle of Protein-Dye Binding. Anal. Biochem. 1976, 72, 248-254. [CrossRef]

36. Meyer, F.; Frey, R.; Ligibel, M.; Sager, E.; Schroer, K.; Snajdrova, R.; Buller, R. Modulating Chemoselectivity in a Fe(II)/ $\alpha-$ Ketoglutarate-Dependent Dioxygenase for the Oxidative Modification of a Nonproteinogenic Amino Acid. ACS Catal. 2021, 11, 6261-6269. [CrossRef]

37. Papadopoulou, A.; Meierhofer, J.; Meyer, F.; Hayashi, T.; Schneider, S.; Sager, E.; Buller, R.M.U. Re-programming and Optimization of a L-proline Cis-4-hydroxylase for the Cis-3-halogenation of Its Native Substrate. ChemCatChem 2021, 1-7. [CrossRef]

38. Hüttel, W. Biocatalytic Production of Chemical Building Blocks in Technical Scale with $\alpha$-Ketoglutarate-Dependent Dioxygenases. Chemie-Ingenieur-Technik 2013, 85, 809-817. [CrossRef] 